\title{
Community Development Model through Development of Thematic Village as a Local Economic Empowerment Efforts in Semarang City
}

\author{
Fitriyah $^{1}$, Nunik Retno Herawati ${ }^{2}$ \\ \{nunikretno92@gmail.com ${ }^{1}$ \} \\ Universitas Diponegoro, Indonesia ${ }^{1,2}$
}

\begin{abstract}
This article basically aims to get a picture of the Community Development Model through the Thematic Kampung development program in Semarang City and to get a picture of regional progress as a result of the Thematic Kampong program in the City of Semarang. This study used qualitative research methods. Sources of data collected in this study are primary data and secondary data. Primary data is carried out by observing and interviewing directly with the Semarang City Regional Development Planning Board (Bappeda) and conducting observations to several Thematic village locations in Semarang City. While secondary data used in this analysis are data from various documents and news in the mass media. The results showed that the success of the Thematic Village in the City of Semarang is inseparable from the support of good cooperation between the Government, Community and Private Sector. However, the community hopes that not only infrastructure is built, but the community is also given training and given a network for marketing products from Thematic Village so that the community is able to independently improve their welfare.
\end{abstract}

Keywords: Community, Development, Village.

\section{Introduction}

Poverty is a major problem for developing countries. This problem is a serious concern each year because a large poor population will certainly be a burden for the progress of a country. Poverty today is no longer only at the rural level but has mushroomed into urban areas. The easiest and most obvious from the face of urban poverty is the condition of millions of people living in slums and squatter settlements. This slum condition shows the serious socio-economic, political and environmental problems which lead to poverty. The city of Semarang as the capital of Central Java is also inseparable from the problem of urban poverty. Table 1 shows that the number of poor people in the city of Semarang is in the range of $5 \%$ $6 \%$ of $1,658,552$ people (December 2017) spread in 16 sub-districts 177 villages.

Table 1. Number of poor populations of Semarang City in 2011-2018

\begin{tabular}{|c|c|c|c|c|c|c|c|c|}
\hline \multirow{2}{*}{ Years } & \multicolumn{7}{|c|}{ Number of poor people (soul) } \\
\cline { 2 - 9 } & 2011 & 2012 & 2013 & 2014 & 2015 & 2016 & 2017 & 2018 \\
\hline Semarang City & 88.453 & 83.346 & 86.734 & 84.640 & 84.270 & 83.590 & 80.860 & 73.650 \\
\hline
\end{tabular}

Source: Semarang City BPS downloaded from https://semarangkota.bps.go.id/. 
Efforts to accelerate poverty reduction continue to be carried out by the Semarang City Government by coordinating and synergizing various poverty alleviation and unemployment activity programs in Semarang City through the "Great Gate" (Joint Movement for Poverty and Unemployment Reduction through Economic Harmonization, Education, Eco-system and Community Ethics). These efforts are in line with the Vision of the Semarang City MediumTerm Regional Development Plan for 2016-2021, namely "Semarang City of Great Trade and Services Towards a More Prosperous Community". With the slogan "Move Together to Build Semarang" which is an attitude that is manifested in the form of initiative and passion to contribute energy and thoughts in order to build the City of Semarang. It is hoped that in the next five years the people of Semarang City will increasingly improve their welfare by meeting the needs of education, health, basic services and supporting facilities and infrastructure.

Thematic Village is one of the Semarang City Government's innovations to overcome the problem of meeting basic needs primarily in improving the quality of the environment of poor people's homes and basic infrastructure of settlements. Thematic Village is the target point of a part of the Village that is being repaired by taking into account the following matters: (1). change the location of slums to not slums/improvement/improvement of environmental conditions, (2). intensified area greening, (3). active involvement of community participation, (4). raise the social and economic potential of the local community (empowerment).

Benefits and impacts of Thematic Villages: First, better fulfilling and improving environmental facilities and infrastructure (public facilities and social facilities). Second. Growth and improvement of the local economy which has the potential to increase family income. Third, Supporting the trademark of the region becomes iconic, can have a positive influence on local residents such as changes in people's mindset and behavior, community empowerment. Fourth, it is also expected to have a positive influence and magnetism for other villages in the Village and other Villages so that they are triggered and encouraged to realize similar themes. Fifth, the emergence of new visiting points in each Sub-district/Village which are not all centralized at the City level (building centers, gallery houses) that support the development of the potential and icons of the City of Semarang. Sixth, it is expected to inspire CSR Givers to replicate Thematic Villages in other villages.

It is hoped that this Thematic Village can be realized in all Villages in the City of Semarang with the following phases: through the 2016 APBD Amendment build 32 Thematic Villages in 32 Sub-Districts 16 Sub-Districts (1 Sub-District 2 Sub-Districts) with a budget of Rp. 200 million. Through the 2017 Revised APBD, building 32 Thematic Villages in 32 Village 16 sub-district (1 sub-district 2 Village) with a budget of @ Rp 200 million. Acceleration through the 2017 Musrenbang proposal in the remaining 113 Village (pure 2018 budget taken from part of the Development Plan Deliberation Fund allocation for each Village, with a budget of Rp 200 million/point). And through CSR assistance and/or nonregional revenue budget Semarang City.

After being implemented for approximately 2 years, of course the Thematic Village development program has brought a number of changes and progress in several areas in the city of Semarang. This article basically aims to get an overview of the Community Development Model through the Thematic Village development program in Semarang City and the efforts and impacts of the Thematic Kampong program in Semarang City.

The problem that will be the focus of this research is how the Community Development Program implemented by the Semarang City Government. The results of this research will give birth to several scientific concepts which in turn will contribute to the development of Government science, especially relating to the implementation of government policies in order 
to develop the potential of the community to creating a prosperous society. The community can know the importance of empowerment for the community to improve the welfare of the community both in social and economic aspects.

\section{Research Methods}

This study used qualitative research methods. The reason for using qualitative methods is because the problem is unclear, holistic, complex, dynamic and meaningful so that it is not possible to capture data on social situations using quantitative research methods. In addition to qualitative research, researchers intend to understand social situations in depth [1]. Sources of data collected in this study are primary data and secondary data. Primary data is done by conducting observations and direct interviews. While secondary data used in this analysis are data from various documents and news in the mass media. The data needed for this research was collected using observation, interview and documentation techniques. Through these three techniques, the research results are expected to be more objective or able to describe the situation as it is.

\section{Discussion}

\subsection{Definition of Community Development}

In theory, community development consists of two concepts, namely "development" and "community". In short, development is a joint and planned effort to improve the quality of human life. It has been mentioned that the concept of community is a group of people with a shared identity. Therefore, community development depends on interaction between humans and joint action rather than individual activities which some sociologists call 'collective institutions' [2].

Development itself according to the United Nations is Development is a process that is designed to create economic conditions and social progress for the community associated with active participation and to fulfill the possibility of trust in community initiatives. There are two communities themselves, namely rural communities and urban communities. Development is the process of increasing choices, in the sense of new choices, diversification, thinking about issues differently and anticipating change [3]. Community development enhances the community's collective ability to make better decisions about the use of resources such as infrastructure, labor and knowledge (figure 1). 


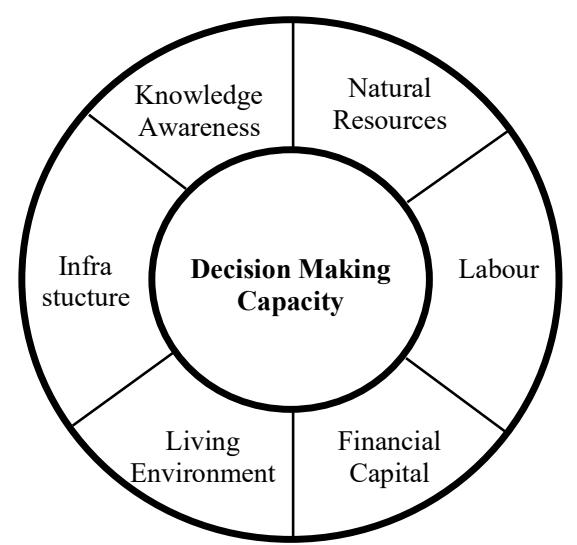

Fig. 1. Community Development (Jim Cavaye, Understanding Community Development).

The key elements of community development are expressed in various definitions. Some of the main descriptions are as follows: For community development to occur, people in the community must believe working together can make a difference and manage to meet their collective needs [4]. Community development is a group of people in a community who reach a decision to begin a process of social action to change their economic, social, cultural and cultural environmental situation [3].

Community development is a process that increases choices. It creates an environment where people can use their full potential to produce productive, creative life results [5]. Community development is a process whereby people unite with the existing authority of the government to improve the economic, social and cultural conditions of society and society are integrated into the life of the nation which enables them to contribute fully to national progress [6].

Community capacity building is the combined influence of community commitment, resources and skills that can be used to build community strength and address community problems and opportunities [7]. Community vitality is the capacity of the local socioeconomic system to survive and survive in generating jobs, income, and wealth and to maintain it if it does not improve its relative economic position [5].

Community economic development is about identifying and utilizing local community resources and opportunities and stimulating sustainable economic and work activities [8]. Sanders [9] sees the development of society as a process that moves from the stages of stages; a method for achieving a goal; a program of procedures and as a movement.

Community development is often associated with terms such as building community capacity, community vitality, empowerment, rural development or independence. The basic elements of collective action, ownership and improved circumstances are common to all of these ideas. There might be a slight difference in emphasis. While community capacity building focuses on enhancing community assets and capabilities, the term is basically synonymous with community development.

\subsection{Community Development or Economic Development?}

Economic development is part of community development. Local industry Development involves the facilitation of relatively small industry groups dealing with specific issues, such 
as discussion groups or market alliances. This is part of economic development. Economic development involves many elements of community development, such as participation, rethinking, learning actions etc. However, it specifically aims to improve the relative economic position of the community. Flora et al, [4] argue that it does not always lead to an improvement in the quality of life or also involves "collectivity". Economic development is largely aimed at increasing employment, income and community economic base.

Economic development is part of community development, which aims to build society, not only improving the community's economy but also the environment, social structure, attitudes and assets (figure 2).

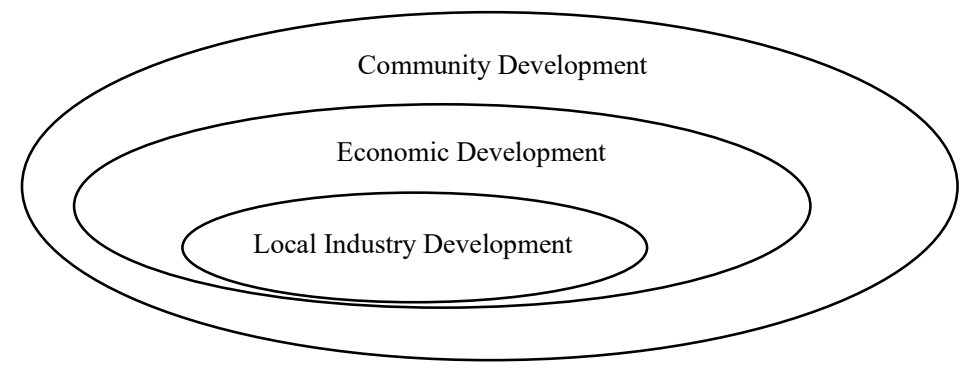

Fig. 2. The Relationship between industry development, economic development and community development [4].

Practitioners debate whether community development or economic development comes first Some argue that society needs work and income before wider social and human development can occur. Others maintain that new attitudes of knowledge, together with larger organizations and broader relationships in society, support economic development. Many practitioners describe community development as the economic development of the community. Regional development is the joint production of communities, local governments and supporting sector institutions, with collaboration from the private sector and nongovernmental organizations (see figure 3).

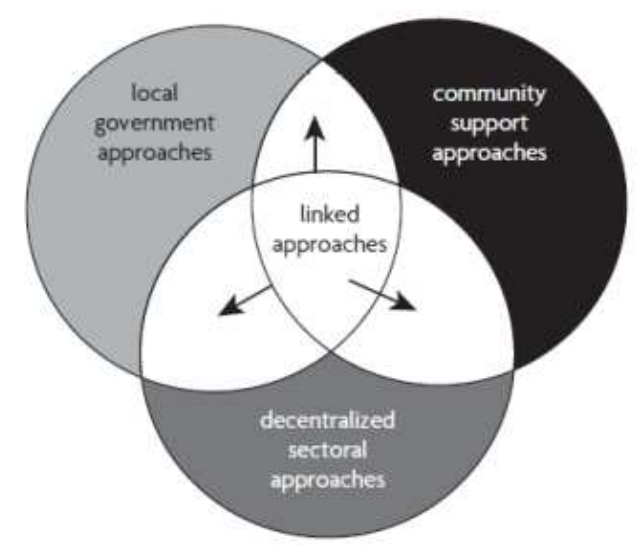

Fig. 3. Linked Approaches [10]. 


\subsection{Community Development Process}

The key to community development is to facilitate the community in applying principles to guide a range of flexible actions that are appropriate for the Community situation. There are many "models" and frameworks for community development processes. There are trade-offs between communities that have a clear future plan for the steps in the process and maintain flexibility and flexibility. Large skills, self-confidence and assessment are needed to maintain an adaptable community process guided by the principle of community development.

Community development never ends. Special development initiatives have a cycle of initiation, expansion, maturity and conclusions. Development, as a process of organizing, rethinking, making decisions and increasing community capital continues. Communities need to continually strive to expand their resource base and their ability to manage change. This means continuous investment of time and effort in the community and new coaching of community leaders and motivation.

The United Nations (UN) defines community development, as 'a process designed to create economic conditions and social progress for all people with their active participation' (UN, 1955). Initially, the aim was to promote integrated development and independence, especially those focused in rural communities, (with the subsequent addition of programs directed at urban communities) [11]

\subsection{Nature and Objectives of Community Development}

Sanders [9] sees community development as a process of moving from one stage to another, a method for achieving goals, a program procedure and as a movement sweeping people in emotions and beliefs. The objectives of community development include:

a) Gives confidence to yourself;

b) Gives a sense of pride, enthusiasm, and passion for work;

c) Increasing dynamics to build;

d) Improving community welfare.

In achieving its objectives, community development must be carried out holistically or in a multi-disciplinary manner to improve community welfare. In addition, the thing to remember is that humans are dynamic so interventions can be developed to develop society. Dynamic means that humans continue towards the truth and not stop. Humans never finish and never reach the finish point. This dynamic nature also touches on the question of evolution and history. Human knowledge is influenced by history, social environment, culture, and individual factors. Therefore, when humans are given intervention and empowered, it is most likely to be able to change, from not knowing to knowing, from not wanting to being willing, and from being unable to being able.

\subsection{Community Development Strategy and Planning}

Community development is seen as the right strategy to empower and improve the standard of living of the wider community. But keep in mind that each community has different traditions and customs, which can be potential that can be developed as social capital. For this reason, in an effort to develop the community, appropriate strategies and approaches are needed. In addition, it is also necessary to discuss community development in the context of various approaches that can be seen as alternative ways of carrying out community development. 
The community development strategies revealed include rational-empirical, normativereeducate and power-coercive. Rational-empirical focuses on a research base by several experts. Whereas normative-reeducate is more related to the attitudes and value systems of community members. In contrast to these two strategies, power-coercive is more related to power relations where the power tends to be forced on the community [12].

The basic assumptions of community development strategies in production centered development state that the assumptions about the community are seen as traditional communities and have low knowledge. So, to advance the community needed external knowledge. The consequences of planning are top-down, centralized, planned by experts and prioritizing macroeconomic growth planning. The consequences of the treatment of the community position experts as the party served by the community so that the implications for social life more cover the existing reality. Whereas the type of people centered development assumes that the community is built not because they are stupid or incapable, but their capabilities are optimized according to local knowledge and appropriate technology as the basis for community development. The consequences of this planning emphasize aspects of locality, autonomous planning based on locality and community participation and the idea of autonomy is emphasized based on micro needs. So, that the consequences of community treatment position experts as facilitators that have implications for social life that is more open to reality.

\subsection{Development of Thematic Villages in Semarang City}

The idea of the Thematic Village was initiated by Semarang Mayor Hendrar Prihadi as the Chosen Mayor of the 2016-2020 period which was later formalized in Semarang Mayor Regulation Number 22 of 2018 concerning Guidelines for Thematic Village Implementation. Thematic village is an area under the administration of the village that shows the identity/identity/meaning of the community over a local potential that is raised and highlighted on the results of community agreement. The purpose of holding Thematic Villages is to improve the welfare of the community through increasing local potential, improving the quality of the residential environment and raising local wisdom in managing potential and solving economic, social and environmental problems.

The output expected from Thematic Villages is the establishment of Thematic Villages based on community empowerment and improvement of the quality of the residential environment, the formation of community understanding and concern for the characteristics and potential of the region and solving existing problems together, and the formation of community enthusiasm in developing themselves and the region. While the outcome of Thematic Village is socially, the formation of personalities and behavior of people who care about the environment. Economically, the achievement of people's welfare through economic rotation based on local potentials raised. In the field of infrastructure, a better and more ordered quality of the settlement environment is realized: good environmental roads; good drains, and good sanitation and greening.

The stages of the implementation of the Thematic Village began with the exploration of potentials and problems by the subdistricts, wards and communities. There are several indicators in determining the theme for Thematic Villages. Socially priority areas with high poverty rates, have the potential for areas that can be developed through empowerment, as well as having urgent social problems. Economically based on areas that have local potential as an economic driver through Natural/Environmental Resources and Human Resources. In addition, priority is given to having productive community groups and products produced by 
local communities. In infrastructure, slum areas or neighborhoods are chosen, or areas and arid residential areas, irregular and regions that experience a decrease in carrying capacity.

The next stage is the preparation of a draft proposal that contains the background, potential, problems, existing design, follow-up plans and costs. The Draft Proposal prepared by the Sub-District, Village and community and the community is subsequently verified by the Regional Development Planning Board and other Regional Apparatus Organizations such as the Office of Cooperatives and Micro, Small and Medium Enterprises, the City Planning and Housing Agency, the Sanitation and Parks Department, the Health Office, the Industry and Trade Office, Community Empowerment and Family Planning Agency.

Only after obtaining approval is field supervision conducted to check the suitability of proposals and conditions in the field. After obtaining approval, a Mayor Decree will be determined to become a Thematic Village. Semarang Mayor Hendrar Prihadi appoints the Semarang City Regional Development Planning Agency as the agency responsible for the planning process to the evaluation stage.

Thematic Village in Semarang City is divided into 3 stages, namely in the first stage in 2016, it was formed in 32 village in 16 sub-districts, the second phase in 2017 was formed in 80 village in 16 sub-districts and the third phase in 2018 was formed in 65 village in 16 subdistricts in Semarang City. So, in total there are 177 Thematic Villages in Semarang City.

From the results of observations made in 18 Thematic Villages in the city of Semarang showed that around $60 \%$ succeeded and $40 \%$ less successful. The success is shown by the existence of physical buildings/infrastructure which are neat, clean, green and beautiful. In addition, the people in the region become productive, creative and innovative. Other indicators seen from the togetherness and kinship of the community are increasingly strengthened in creating productive business networks. While conditions are less successful shown from the existence of an untreated environment, apathetic society, and the development of productive community businesses.
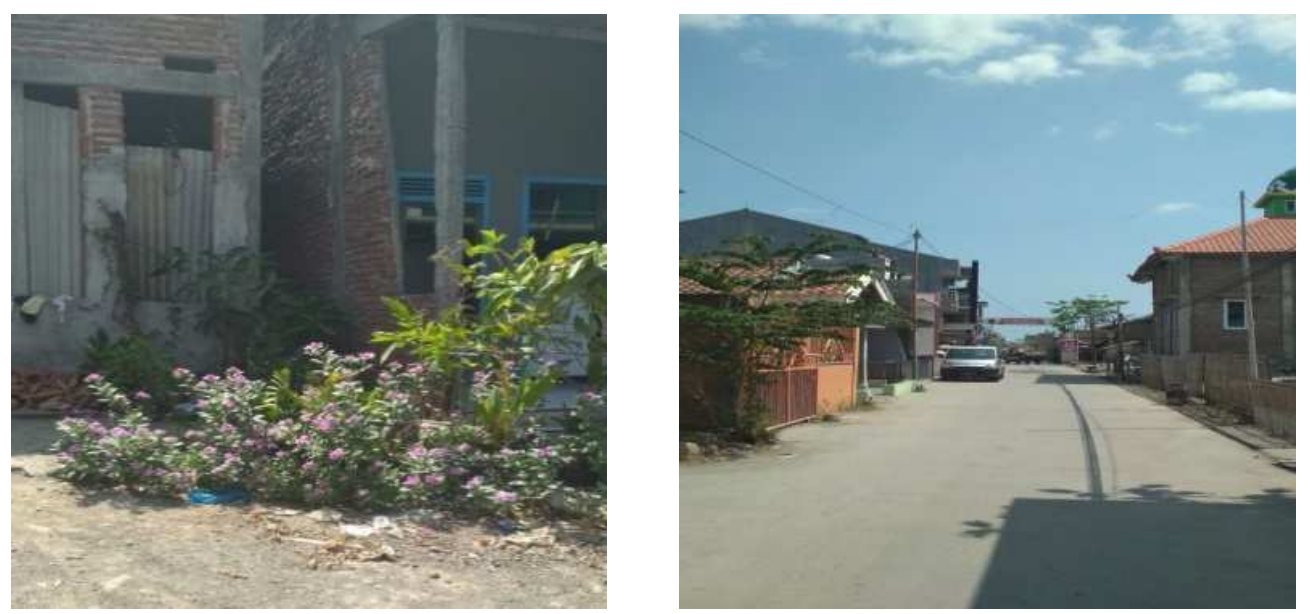

Fig. 4. Thematic Villages that Are Less Successful (Hydroponic Village, Tanjung Mas Village, North Semarang District) Source: Researcher Documentation. 

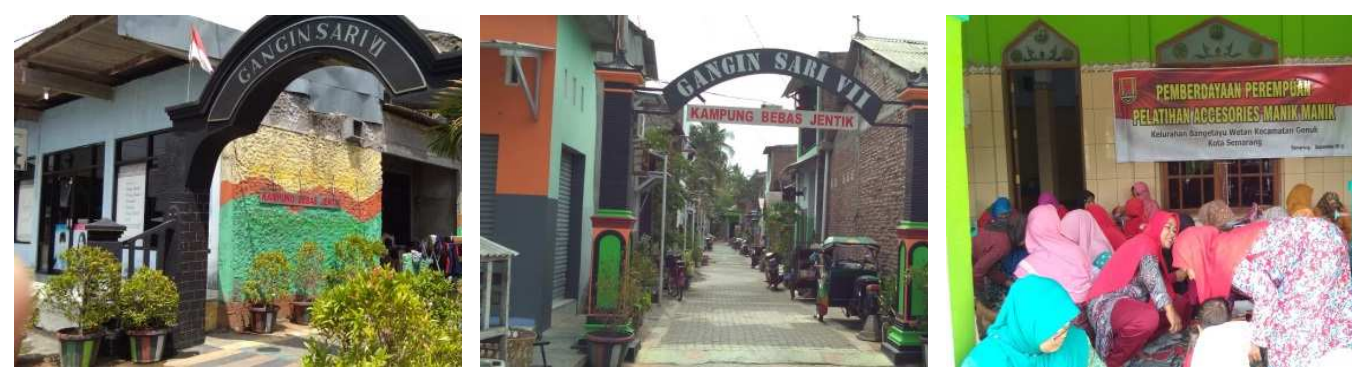

Fig. 5. Successful Thematic Villages

(Mosquito Free Thematic Villages in Bangetayu Wetan, Genuk, Semarang City)

Source: Researcher Documentation.

The main obstacle of the implementation of thematic villages in the city of Semarang is the lack of community participation in managing program activities. The general public is still lacking in awareness to manage programs in their area and develop programs initiated by the Semarang City Government. At first the formation of Thematic Villages was very enthusiastic, but in its development, many were left neglected and neglected.

The success of the Thematic Village in the City of Semarang is inseparable from the support of good cooperation between the Government, Community and Private Sector. For example, for example, Child Friendly Health Village in Kuningan sub-district, Semarang subdistrict north of Semarang City. In this village, many parties took part in creating a childfriendly Healthy Village in addition to the Semarang City Regional Development Planning Agency including the Office for Women's Empowerment and Child Protection (DP3A). In its implementation, the Child Friendly Healthy Village also received facilities from universities, namely Semarang State University through the Community Service Program (KKN). There is even a social organization, the Semarang Rotary Club, which plays a role in providing training in processing waste into useful and valuable items.

There is some hope from the community for the Semarang City Government to pay attention to environmental conditions and the potential that truly exists in the community in planning and implementing programs whose purpose is to prosper the community. In addition, the community hopes that the Semarang City Government will not only help programs that are physical in the form of infrastructure development, such as the construction of the Village Identity Gate, but are more focused on developing Human Resources so that they are willing to change and are empowered economically, socially and culturally. And more important is the participation and involvement of the community in planning, implementing and supervising community development policies and programs.

\section{Conclusion}

Although not all Thematic Villages in Semarang City have succeeded as expected by the Government, the Thematic Village innovations initiated by the Mayor of Semarang have had a positive impact on the community. In addition to the neat and beautiful environment of the region, small and medium enterprises in the community also developed. The success of the Thematic Village is determined by the participation of the community and the support of various stakeholders and shareholders such as Universities, Non-Government Organizations 
and Community Organizations and the private sector. Collaborative involvement and collaboration between the Government, Community and Private Sector will produce progress and prosperity for the community.

\section{References}

[1] Sugiyono, Metode Penelitian Kuantitatif, Kualitatif dan $R \& D$. Bandung: Anggota Ikatan Penerbit Indonesia (AIPI), 2013.

[2] C. B. Flora and J. L. Flora, "Entrepreneurial social infrastructure: A necessary ingredient," Ann. Am. Acad. Pol. Soc. Sci., vol. 529, no. 1, pp. 48-58, 1993.

[3] J. W. Christenson, J.A. and Robinson, Community Development in Perspective. Iowa State University Press, 1989.

[4] C. B. Flora, J. Flora, J. Spears, L. Swanson, M. Lapping, and M. Weinberg, "Rural communities: legacy and change (Boulder, CO.” Westview Press, 1992.

[5] R. Shaffer, "Community economics," Econ. Struct. Chang. Smaller, 1989.

[6] S. Biggs, "Community capacity building in Queensland: The Queensland Government service delivery project," Unpubl. Pap. Off. Rural Communities, Brisbane, Queensl., 1999.

[7] A. Institute, "Measuring community capacity building: A workbook-in-progress for rural communities." The Aspen Institute Washington, DC, 1996.

[8] P. Kenyon, "Ready set go: Action manual for community economic development," Melb. Munic. Assoc. Victoria, 1994.

[9] I. T. Sanders, Theories of Community Development. 1958

[10] H. P. Binswanger-Mkhize, J. P. de Regt, and S. Spector, Scaling up Local and Community Driven Development: A real world guide to its theory and practice. World Bank, 2009.

[11] S. Braden and M. Mayo, "Culture, community development and representaion," Community Dev. J., vol. 34, no. 3, pp. 191-204, 1999.

[12] G. W. Silavwe, "Community development programmes in Zambia: an evaluation and assessment of events," Community Dev. J., vol. 19, no. 3, pp. 167-175, 1984. 